AperTO - Archivio Istituzionale Open Access dell'Università di Torino

\title{
Energy and moisture losses during poplar and black locust logwood storage
}

\section{This is the author's manuscript}

Original Citation:

\section{Availability:}

This version is available http://hdl.handle.net/2318/1616651

since 2016-11-25T14:20:59Z

Published version:

DOI:10.1016/j.fuproc.2015.05.026

Terms of use:

Open Access

Anyone can freely access the full text of works made available as "Open Access". Works made available under a Creative Commons license can be used according to the terms and conditions of said license. Use of all other works requires consent of the right holder (author or publisher) if not exempted from copyright protection by the applicable law. 


\section{logwood storage}

\section{Abstract}

7 The main problem with firewood production is the same as for other wood biofuels: storage.

8 Usually, firewood is stored in logwood. The goal of this study was to determine the drying storage dynamics of logwood used for firewood production under the typical work conditions forest practise of southern Europe. Storage dynamics were evaluated for two different forestry tree species (poplar and black locust) with logwood disposed in uncovered piles for a period of 180 days (March-September). In this study, the effect of the diameter of logs and their position inside the pile on wood drying was evaluated. In each treatment This evaluation was performed considering the main key drying physical parameters were monitored - temperature (T), moisture content (MC), heating value (HV) and dry matter (DM). The study found that initial values of key parameters were different for both forestry species, but at the end of the storage period the values were considered to be similar $\left(19^{\circ} \mathrm{C} \mathrm{T}, 19 \% \mathrm{MC}, 14.30 \mathrm{MJ}\right.$ $\mathrm{kg}^{-1} \mathrm{LHV}$, no DM losses). No statistically significant differences were pointed out between logs with different diameter sizes and different positions in the pile. For this reason, drying firewoed logwood in uncovered piles can be considered a good storage method irrespective of forestry species, the diameter of logs and the position of logs in the pile. Keywords firewood, logwood, moisture content, energy content, black locust, poplar 


\section{Introduction}

3 Firewood is a form of energy wood that is still used today globally as an alternative to fossil fuel

4 [1]. This biofuel is used especially in developing countries [2]. In industrialised countries, in fact, 5 the widespread use of firewood is limited to only rural areas [3]. In Europe, chopped firewood is

6 still used more than any other industrial energy wood product [4], especially in northern countries 7 where its consumption covers between 20 and $25 \%$ of the heating needs [5-6]. In southern Europe 8 (France and Italy), firewood is used, but to a lesser extent than in the rest of Europe [7].

Firewood is preferred to other biofuel because its production process is easier and requires lower investments [8]. Biofuel preparation requires only cross-cutting and splitting the logs extracted from the forest [9]. This operation is even performed by individuals and small businesses or farmers that carry out this activity on a part-time basis [10], not only in northern Europe [11], but also in Southern Europe [12]. Irrespective of the region being considered, the production of chopped firewood can play an important role in economic development where coppice forests are diffused $[13]$.

The main problem with the commercialization of firewood is the same as for other wood biofuels: the moisture content. When wood is harvested in forests its moisture content is higher and not very suitable for direct use in small boilers and domestic stoves [14]. In fact, the quality of energy wood is proportional to its calorific value, which is higher when the moisture content is lower [15]. Nevertheless, moisture losses can decrease significantly by storing energy wood in piles for a short period of time only [16]. Until now, many works have focused on the storage dynamics of woodchips. Some of these have studied the influence of the forestry species used for woodchip production - poplar [17], Salix [18] or pine [19] - while others have analysed the effect of 
woodchip pile weight [18], drying methods [20] and storage techniques used [21-22]. Little has been done regarding the storage of energy logwood.

In contrast to woodchips, drying logwood shows low dry matter losses (2\% per year) [23] because during the storage period, microbial activities are lower than in comminuted wood [24]. Another advantage of drying logwood is the economic benefit. In fact, drying wood for energy with this method showed an increase in its market value of $14,40 \mathrm{€t}^{-1}$ after five months [16]. In recent years, some experimentations were focused on logwood storage dynamics, especially in terms of moisture content [16, 25-26], but all of these were carried out in northern Europe where the work conditions forest practises are different to those in southern Europe. In fact, in northern Europe, firewood is obtained from logs of 2-6 $\mathrm{m}$ in length, while in southern Europe it is obtained from logs $1-2 \mathrm{~m}$ long, due to the different extraction methods [27-28].

列

On the basis of this, the goal of this study was to determine the drying storage dynamics of logwood used for firewood production under the typical work cenditions forest practises of southern Europe. In particular, the storage dynamics of drying logwood in piles were evaluated for two different forestry tree species.

\section{Materials and methods}

This experiment was carried out at Moncalieri in Turin/Italy $\left(45^{\circ} 00^{\prime} 31^{\prime \prime} \mathrm{N}, 7^{\circ} 42^{\prime} 53^{\prime}\right.$ '; $356 \mathrm{~m}$ above sea level). The study was conducted during 2014 and it lasted for six months (March-September).

In Italy, this period correspond to the usual firewood storage because the wood is harvested until March and starts being used from September. 
1 Generally in Italy, firewood is produced by from only high-density tree species, but in this work, in order to establish eventual differences in drying dynamics, tests were carried out using both highdensity tree species (black locust - Robinia pseudoacacia) and low-density tree species (poplar Populus x euroamericana). Hybrid poplar and black locust are most common on North Italian farmland and normally used for energy production, which is why they can be considered representative of the two wood categories [29].

(1)

Storage dynamics were assessed through variations in moisture and temperature taking into account different logs' diameter and position in the pile. Temperature and moisture content are reliable indicators of wood storage performance used for energy production [30]. Therefore, moisture content and temperature inside the logs were monitored over the whole storage period, which began in March with the preparation of logs and ended in September with usage of the wood.

In order to maintain logs in the same position over the whole storage period, in this experiment moisture content was not determined by gravimetric method, but was monitored by a digital hygrometer (accuracy of \%o) normally used in sawmills (GANN@Hydromette HT85T). This device, designed for registering external moisture, presents a probe with two short steel electrodes (20 mm). Since in the test the measurement point was D/2 for each diameter class, specific probes with steel electrodes of different lengths were made. In order to obtain only the moisture measurement at the top of the probe (half of the log diameter), the electrodes were covered with electrical tape up to 5 $\mathrm{mm}$ from its top. The probes were positioned at the middle length of the logs (about $1 \mathrm{~m}$ from the head). All logs used in the test had a length of about 2 metres because this is a common length that is commercialized in unprocessed energy wood in Italy [27].

The temperature was measured by thermocouples placed near the probes for determining moisture content. 
1 The influence of log diameter on wood drying was evaluated by monitoring the moisture content of

$2 \operatorname{logs}$ of different diameters $(50,100,150,200$ and $250 \mathrm{~mm})$.

3 All logs, equipped with thermocouples and probes, were placed outdoors on two transversal logs

4 positioned on the soil at a distance of $300 \mathrm{~mm}$ apart. The logs were placed with their longitudinal

5 axis orientated south-north and left uncovered for the entire storage period. Data were collected

6 every three days for the first 30 days, thereafter every 15 days (Fig. 1).

7 For each diametric class and for each trestry tree species, measurements were carried out on three 8 different logs (three repetitions). Table 1 reports the experimental design.

The influence of the position of logs in the pile on drying wood was analysed by making two uncovered piles (one of poplar and one of black locust) on naked soil and aligning their longer axis in an east-west direction. The experimentation was conducted with uncovered piles made on naked $\underline{\text { soil because this is the usually forest practice used for logwood storage in all European countries }}$ [25-26]. A single pile had a volume of approximately $60 \mathrm{~m}^{3}$ (12 $\mathrm{m}$ long, $2 \mathrm{~m}$ wide and $3 \mathrm{~m}$ high). The wood moisture content was measured by a probe prototype described in a previous test. Each probe was placed halfway $(1 \mathrm{~m})$ along the logs and was $150 \mathrm{~mm}$ in diameter and 2 metres in length. The reading of moisture content was performed only at the mid-diameter of the logs.

Logs with probes were placed in the pile, at seven different heights above the ground $(0,0.5,1.0$, 1.5, 2.0, 2.5 and 3.0 metres). At each sampling height three logs were positioned at a distance of 1 metre apart (Fig. 2).

The complete experimental design consisted of 21 replicates per forestry tree species (poplar and black locust) (Table 2). 
1 Near the piles, a weather station was installed in order to monitor air temperature $\left({ }^{\circ} \mathrm{C}\right)$, air humidity

$2(\%)$, precipitation $(\mathrm{mm})$ and wind speed $\left(\mathrm{ms}^{-1}\right)$ at $1 \mathrm{~h}$ intervals. All measuring components were installed at a height of $1.7 \mathrm{~m}$ to $2.2 \mathrm{~m}$.

Finally, in order to establish the logwood storage benefits, at the beginning and at the end of the test period the heating value (lower and higher) and dry matter losses of logs were determined. Heating value was determined according to European Standard UNI EN 14918 [31]. In detail, Higher Heating Value (HHV) was tested using an oxygen bomb calorimeter. For this measurement, the wood sample taken from the logs did not show the presence of bark. Dry matter losses were determined for each log diameter class and forestry species (10 treatments with 3 replicates). Each $\log$ was weighed at piling, and then at the end of the storage period. For this test, moisture content was determined with the gravimetric method according to European standard UNI EN 14774-2 [32] because this is more reliable and accurate than probes set up for periodic measurements (previously described) [33]. Initial moisture content was determined using a cutting an end portion of the logs $(150 \mathrm{~mm})$, while the final value was determined by cutting a central portion $(150 \mathrm{~mm})$ of the logs.

Data were processed with the SPSS statistical software, adopting a significance level of $a=0.05$, in order to check on the statistical significance of eventual differences between treatments. In detail, the SSPS software was used to perform typical analysis of variance (ANOVA) in order to see how the sum of square was divided between main effects, interactions and residuals.

\section{Results}

During the investigation period of 180 days, air temperature ranged from 5 to $25^{\circ} \mathrm{C}$, with a mean value of $17^{\circ} \mathrm{C}$. The mean wind speed was $0.52 \mathrm{~ms}^{-1}$ during the test period. The maximum wind speed was $6.71 \mathrm{~ms}^{-1}$ and the dominating wind direction was from the south-east. The relative 
1 humidity was fairly constant, with a monthly average of between $75 \%$ and $83 \%$, and highs during rain events (Fig. 3). In all periods considered, only liquid precipitations were felled. In all, a total of 370 mm was absorbed. Rain was distributed across a dozen main events, each contributing about 9$27 \mathrm{~mm}$ precipitation.

The different forestry tree species tested showed different initial moisture content: approximately $60 \%$ for poplar and about $45 \%$ for black locust. Nevertheless, both species displayed a similar moisture loss trend in which the higher values were observed in the first 30 days. At the end of the storage period considered, irrespective of forestry investigated tree species, all logs had an average moisture content of about $19 \%$ (Fig. 4).

In the firsts 30 days of storage, moisture losses for poplar logwood were inversely proportional to the diameter of the logs. In fact, the highest loss value (61\%) was observed for the smallest diameter $(50 \mathrm{~mm})$, while the lowest moisture $(46 \%)$ was observed for the biggest diameter (250 $\mathrm{mm}$ ). Considering a storage period between 60 and 180 days, the moisture losses were similar for all diameters (Table 3).

This trend was also true for black locust logwood. However, in this case, moisture losses were lower (from $14 \%$ to $26 \%$ ) than for same-diameter poplar logs due to lower initial moisture content (25\%). After 60 days of storage, the moisture content of about $20 \%$ of the logs was tested and no difference between logs with different diameters was observed (Table 3).

In the "log position" test carried out with poplar wood a significantly different moisture loss from logs placed at different heights from the ground in the first 30 days of storage was observed. Nevertheless, this difference was clearly visible only in the first 10 days where logs near the soil were highlighted as lower drying (35\%) than those positioned at a higher height (42\%). Also in this 
case, after a storage period of 60 days, all logs showed a similar moisture content below 20\% (Table 2).

(1)

Similar results were obtained using black locust logs. In fact, considering the same storage period of 10 days, the moisture loss variance between logs near the soil and others placed at a higher level was similar (5\%) to that of poplar (7\%). No differences between the moisture content of logs were observed after 60 days of stacking (Table 4).

At the end of the storage period considered (180 days), data processing highlighted no statistical differences between the forestry $\underline{\text { tree }}$ species, diameter size and position in the pile of logs (Table 5).

Similar values were also obtained after 60 days of storage, but in this case there was a significant difference between the content than the black locust (Table 6).

During the test, all logs showed similar internal temperature values to air temperature values in all treatments tests. Initially, internal $\log$ temperatures were about $3{ }^{\circ} \mathrm{C}$, while at the end of the storage period the temperatures increased to about $20^{\circ} \mathrm{C}$.

No statistical differences between values recorded by thermocouples placed among the poplar logs and values read by the weather station were observed in either test type performed ("log diameter" and "log position"). The same dynamics were recorded with the black locust logs. Data processing also showed no significant value differences between poplar and black locust (Tables 7 and 8).

Table 7: Air temperature and internal temperature of logs of $100 \mathrm{~mm}$ in diameter of different forestry species placed at different heights in the pile during whole storage period.

5 Poplar, with an average of $18.74 \mathrm{MJ} \mathrm{kg}^{-1}$, showed an initial HHV higher than black locust, which obtained only an average value of $18.04 \mathrm{MJ} \mathrm{kg}^{-1}$. On the other hand, initial LHV was high for black 
1 locust (7.75 $\mathrm{MJ} \mathrm{kg}^{-1}$ ) and low for poplar (7.05 $\left.\mathrm{MJ} \mathrm{kg}^{-1}\right)$. At the end of the storage period, no

2 significant variations were obtained in HHV values, while substantial variations were observed in

3 LHV values. In detail, final LHV values were similar for all forestry tree species and treatment test

4 reaching an average value of $14.40 \mathrm{MJ} \mathrm{kg}^{-1}$. This values trend highlighted an LHV increase of

5 approximately $100 \%$ for poplar and of $84 \%$ for black locust. Diameter size and log position inside

6 the pile did not influence the final LHV values (Tables 9 and 10).

7

\section{Discussion}

With regard to the initial moisture content of the different forestry tree species tested, the values obtained in this work are in line with another study carried out with the same forestry tree species [21]. The significant difference in logwood moisture content between the poplar and black locust in the first 60 days of the storage period is similar to that found by Gautam et al [34] in Ontario.

In this work, the moisture content of logs rapidly decreased in the first 30 days of storage. These results are also comparable with the findings of another study carried out in Michigan [26], but in contrast, the wood moisture content decreased for all storage period. This is probably due to the drier climate of Italy, which makes water transfer between wood and air easy and does not permit remoistening of the biomass [35-36]. A similar trend was also observed in woodchip storage where experiments carried out in Italy $[17,21]$ showed better results in terms of wood moisture content than practices performed in northern Europe [37-38]. 
1 Values obtained in during the first 20 days are similar to those reported by Petterson and Nordfiell

2 [39] in Sweden during a storage forestry logging residues and young tree storage in summer.

4 In this study, the moisture content was uniform from top to bottom of the piles for most of the 5 storage period (30-180 days). In contrast, Gingler et al [35] found that the top of the pile has a

6 higher moisture content, while Roser et al [40] reported that the wood moisture content of a pile

7 decreases from top to bottom. This could be attributed to a wetter climate where the experiment was carried out: rainfall can heavily affect biomass moisture content [41]. In contrast, in another study it was pointed out that the bottom layers of the pile showed a higher wood moisture content due to lower ventilation and soil moisture [42]. On the basis of this, it is possible to assert that the environmental conditions influenced the drying of the biomass because they interact significantly with water evaporation and wood moisture content [43].

Moreover, in this work it is pointed out that the diameter of logwood did not interfere with wood drying when the storage period was more than 30 days long. Also, in this case, results are similar to those found by Gautam et al [34], although in their study only branches with diameters higher and lower than $40 \mathrm{~mm}$ were compared. In this regard, readers must remember that the short length (2 metres) of the logs considered in this experiment may have facilitated the water evaporation from wood irrespective of diameter.

No treatments tests showed any difference between air temperature and temperature values inside the logs. This can be considered as an indication of the absence of biological activities inside the logs/piles, which can be the main cause of dry matter losses [37]. In fact, in this study no dry matter losses were observed in the whole storage period. Such storage dynamics were foreseeable because in previous works drying logwood showed low dry matter losses (2\% per year) [23] due to low microbial activities [24]. 
2 In this study, initial HHV values are in line with those found by Carmona et al [44]. In light of the absence of statistical variation between initial and final HHV values for both forestry species tested, it is possible to assert that during the storage period the wood energy content does not change. This

5 values trend is similar to that observed in other experiments [34,26], but in contrast with other

6 studies [45-46] where authors assert that the HHV is maintained only during the first 4 months and

7 later decreases because the biodegradation process changes the chemical composition of the wood.

8 Results obtained in this work are supported by the effectively restricted microbial activity due to

9 fast wood drying that caused a biomass moisture content of lower than $20 \%$ after only 60 days [47].

In general, logwood storing was carried out very efficiently because of the biomass increasing its LHV by between 83 and $100 \%$ in six months respectively for black locust and poplar. These values were obtained irrespective of the diameters and log positions in the pile. Similar values were found in other works carried out with hardwood [34, 48].

\section{Conclusions}

17 The study found that the initial value of moisture content was different for poplar and black locust, but at the end of the storage period the values were considered to be similar (approximately 19\%). In addition, logs placed in different layers obtained a uniform moisture content because ground soil and rainfall did not increase the presence of water at the bottom and top of the log pile. No statistically significant differences were pointed out either between logs with different diameters. Moreover, the study has pointed out that wood could be considered dried after only 60 days of storing because the values observed in this period are similar to those recorded after 180 days. Similar performances were also obtained in heating value evaluation; in fact, over six months the low heating value can increase to $100 \%$. 
1 On the basis of these considerations, it is possible to assert that drying firewood logwood in uncovered piles showed a good performance in terms of moisture content, heating values and energy content irrespective of log diameter size and position in the pile. Nevertheless, the results obtained in this work are valid only in a dry climate closed to southern Europe.

\section{References}

[1] Guo M, Song W, Buhain J. Bioenergy and biofuel: History, status and perspective. Renewable and Sustainable Energy Reviews 2015;42:712-725.

[2] Keam S, McCormick N. Implementing sustainable bioenergy production; a compilation of tools and approaches. IUCN, Gland, Switzerland (2008) 1-32.

[3] Lillemo S, Halvorsen B. The impact of lifestyle and attitudes on residential firewood demand in Norway. Biomass and Bioenergy 2013;57:13-21.

[4] Nybakk E, Lunnan A, Jenssen J, Crespell P. The importance of social networks in the Norwegian firewood industry. Biomass and Bioenergy 2013;57:48-56.

[5] Halder P, Pietarinen J, Havu-Nuutinen S, Pelkonen P. Young citizens'knowledge and perceptions of bioenergy and future policy implications, Energy Policy 2010;38:3058-3066.

[6] Lindroos O. Residential use of firewood in Northern Sweden and its influence on forest biomass resources, Biomass and Bioenergy 2011;35:385-390.

[7] Elyakime B, Cabanettes A. Financial evaluation of two models for energy production in small French farm forests, Renewable Energy 2013;57:51-56.

[8] Manzone M, Spinelli R. Efficiency of small-scale firewood processing operations in Southern Europe. Fuel Processing Technology 2014;122:58-63.

[9] Lindroos O. The effects of increased mechanization on time consumption in small-scale firewood processing. Silva Fennica 2008;42:791-805.

[10] Kärhä K, Jouhiaho A. Producing chopped firewood with firewood processors. Biomass and Bioenergy 2009;33:1300-1309. 
1 [11] Seppänen A, Kärhä K. The chopped firewood trade in Finland. TTS Institute, Forestry Bulletin 2003;662:1-6.

[12] Spinelli R, Magagnotti N, Facchinetti D. Logging companies in the European mountains: an example from the Italian Alps. International Journal of Forest Engineering 2013. DOI: 10.1080/14942119.2013. 838376.

[13] B. Lasserre, G. Chirici, U. Chiavetta, V. Garfi’, R. Tognetti, R. Drigo, P. DiMartino, M. Marchetti, Assessment of potential bioenergy from coppice forests trough the integration of remote sensing and field surveys, Biomass and Bioenergy 2011;35:716-724.

[14] Nurmi J. The storage of logging residue for fuel. Biomass Bioenergy 1999;17:41-7.

[15] Hartmann H, Kaltschimitt M. Energie aus Biomasse: Grundlagen, Techniken und Verfahren. Springer Verlag. Berlin-Heidelberg-New York 2001. 770 p.

[16] Erber G, Kanzian C, Stampfer K. Predicting moisture content in a pine logwood pile for energy purpuses. Silva Fennica 2012;46(4):555-567.

[17] Barontini M, Scarfone A, Spinelli R, Gallucci F, Santagelo E, Acampora A, Jirjis R, Civitarese V, Pari L. Storage dynamics and fuel quality of poplar chips. Biomass Bioenergy 2014;62:1725.

[18] Jirjis R. effects of particle size and pile height on storage and fuel quality of comminuted salix viminalis. Biomass bioenergy 2005;28:193-201.

[19] Casal MD, Gil MV, Pevida C, Rubiera F, Pis JJ. Influence of storage time on the quality and combustion behaviour of pine woodchips. Energy 2010;35:3066-3071.

[20] Le Lostec B, Galanis N, Baribeault J, MilletteJ. Wood chip drying with an adsorption heat pump. Energy 2008;33:500-512.

[21] Manzone M, Balsari P, Spinelli R. Small-scale storage techniques for fuel chips from short rotation forestry. Fuel 2013;109:687-692.

[22] Ergul E, Ayrilmis N. Effect of outdoor storage conditions of wood chip pile on the technological properties of wood-based panel. Biomass Bioenergy 2014;61:66-72. 
1 [23] Golser M, Pichler W, hader F. Energieholztrocknung. Holzforschung Austria 2005: 138 p.

[24] Petterson M, Nordfiell T. Fuel quality changes during seasonal storage of compacted logging residues and young trees. Biomass Bioenergy 2007;11:782-792.

[25] Erber G, Routa J, Kolstrom M, Kanzian C, Sikanen L, Stampfer K. Comparing two different Approaches in modelling small diameter energy wood crying in logwood piles. Croatian Journal of Forestry Engineering 2014;35(1):15-22.

[26] Lin Y, Pan F. Effect of in-wood storage of unprocessed logging residue on biomass feedstock quality. Forest products journal 2013;63:119-124.

[27] Magagnotti N, Pari L, Spinelli R. Re-engineering firewood extraction in traditional Mediterranean coppice stands, Ecological Engineering 2012;38:45-50.

[28] Zimbalatti G, Proto A. Cable logging opportunities for firewood in Calabrian forests. Biosystems Engineering 2009;102:63-68.

[29] Facciotto G, Bergante S, Lioia C, Mughini G, Rosso L, Nervo G. Come scegliere e coltivare le colture da biomassa, Supplemento Forlener L'informatore Agrario 2005;34:27-30 (in italian).

[30] Fuller W. Chip pile storage - a review of practices to avoid deterioration and economic losses. TAPPI J 1985;68:48-52.

[31] UNI EN 14918. Solid biofuels, determination of calorific value; 2010.

[32] UNI EN 14774-2. Solid biofuels, determination of moisture content - oven dry method, Part 2: total moisture - simplified method 2010.

[33] Samuelsson R, Burvall, Jirjis R. Comparison of different methods for the determination of moisture content in biomass. Biomass Bioenergy 2006;30:929-934.

[34] Gautam S, Pulkki R, Shahi C, Leitch M. Fuel quality changes in full tree logging residue during storage in roadside slash piles in Northwestern Ontario. Biomass Bioenergy 2012;42:4350.

[35] Gigler JK, Van Loon WKP, Van den Berg JV, Sonneveld C, Meerdink G, 2000. Natural wind drying of willow stems. Biomass Bioenergy 19;3:153-163. 
1 [36] Steele PH, Mitchell BK, Cooper JE, Arora S. Bundled slash: a potential new biomass resource for fuels and chemicals. Appl. Biochem. Biotechnol 2008;148(1):1-13.

[37] Jirjis R. Storage and drying of wood fuel. Biomass Bioenergy 1995;9:181-190.

[38] Jirjis R, Thelander O. The effect of seasonal storage on the chemical composition of forest residue chips, Scand J For Res 1990;5:437-448.

[39] Pettersson M, Nordfjell T. Fuel quality changes during seasonal storage of compacted logging residues and young trees. Biomass Bioenergy 2007;31:782-792.

[40] Roser D, Mola-Yudego B, Sikanen L, Prinz R, Gritten D, Emer B, Vaatain K, Erkkila A. Natural drying treatments during seasonal storage of wood for bioenergy in different European locations. Biomass Bioenergy 2011;35:4238-4247.

[41] Pan F, Han HS, Johnson L, Elliot W. Net energy output from harvesting small-diameter trees using a mechanized system. Forest Prod J. 2008;58(1/2):25-30.

[42] Filbakk T, Olav H, Nurmi J. Modeling natural drying efficiency in covered and uncovered piles of whole broadleaf trees for energy use. Biomass Bioenergy 2011;35:454-463.

[43] Bedane AH, Afzal MT, Sokhansanj S. Simulation of temperature and moisture changes during storage of woody biomass owing to weather variability. Biomass Bioenergy 2011;35:31473151.

[44] Carmona R, Nuñez T, Alonso MF. Biomass yield and quality of an energy dedicated crop of poplar (Populus spp.) clones in the Mediterranean zone of Chile. Biomass Bioenergy 2015;74:96-102.

[45] Brand MA, Bolzon de Muniz GI, Quirino WF, Brito JO. Storage as a tool to improve wood fuel quality. Biomass Bioenergy 2011;35:2581-2588.

[46] Nurmi J. The effect of whole-tree storage on the fuelwood properties of short-rotation Salix crops. Biomass Bioenergy 1995;8:245-249.

[47] Hudson H. Fungal Biology. Great Britain: Cambridge University Press;1992, 305 pp. 
1 [48] Hakkila P. utilization of residual forest biomass. Berlin, Heidelberg, New York: springer;

2 1989.

3 


\section{$1 \quad$ Figures}

2

Logs placed on the soil

3

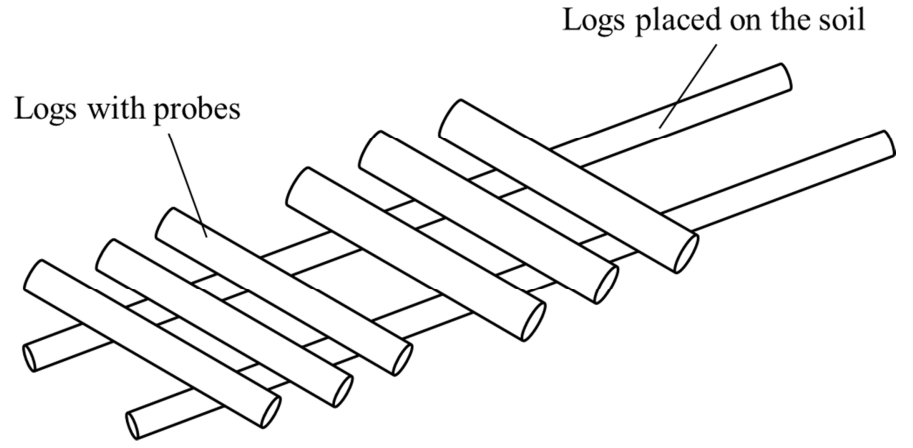

4 Fig. 1: Placement of logs during the test.

5 


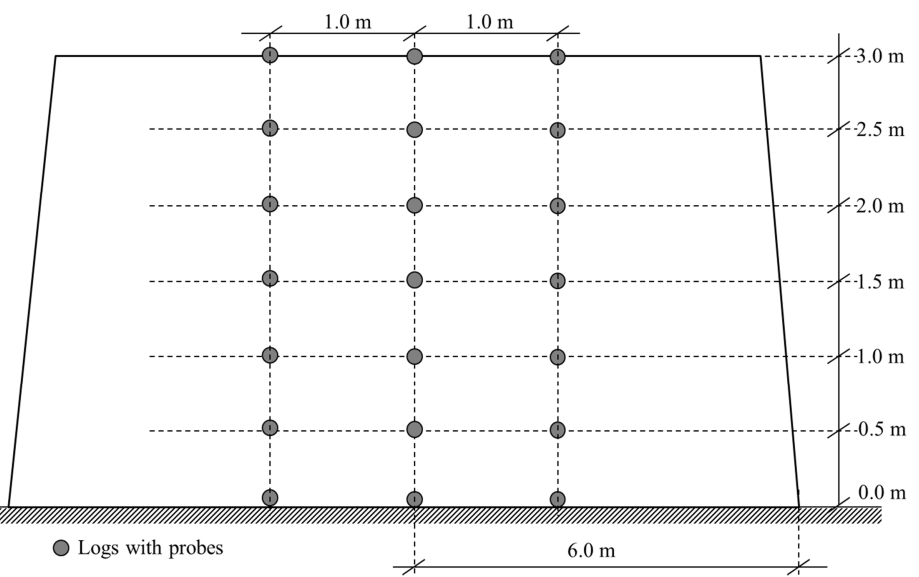

3 Fig. 2: Position of logs with probes in the pile.

4 


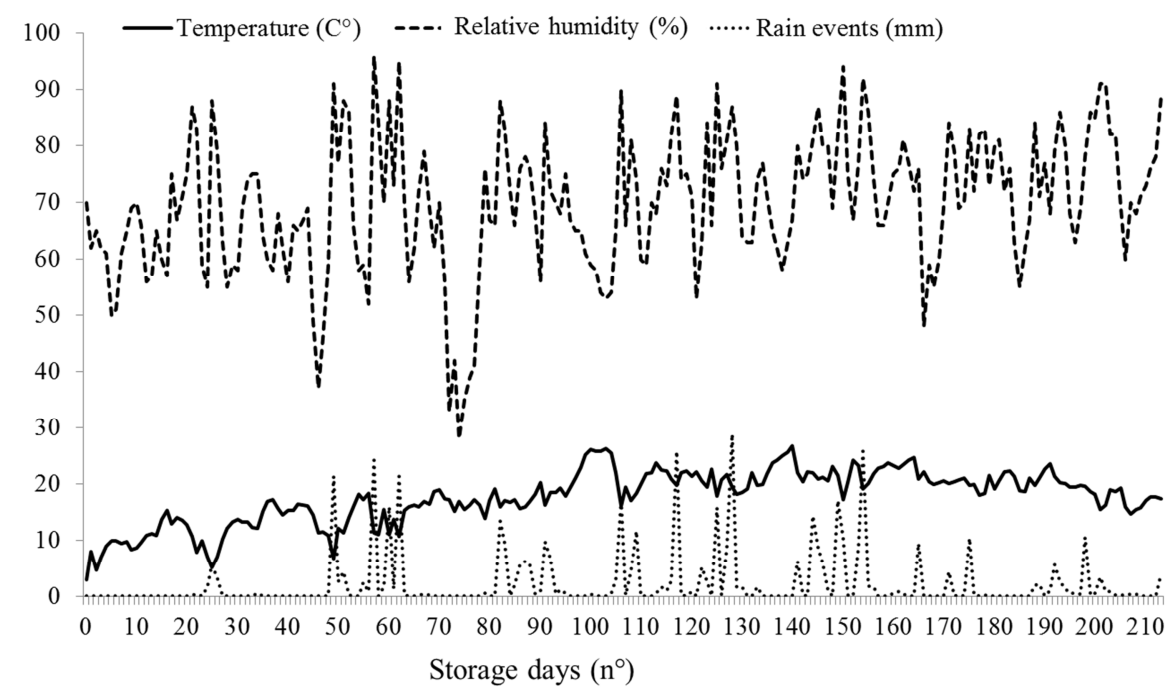

1

2 Fig. 3: Weather data recorded during the storage period. 


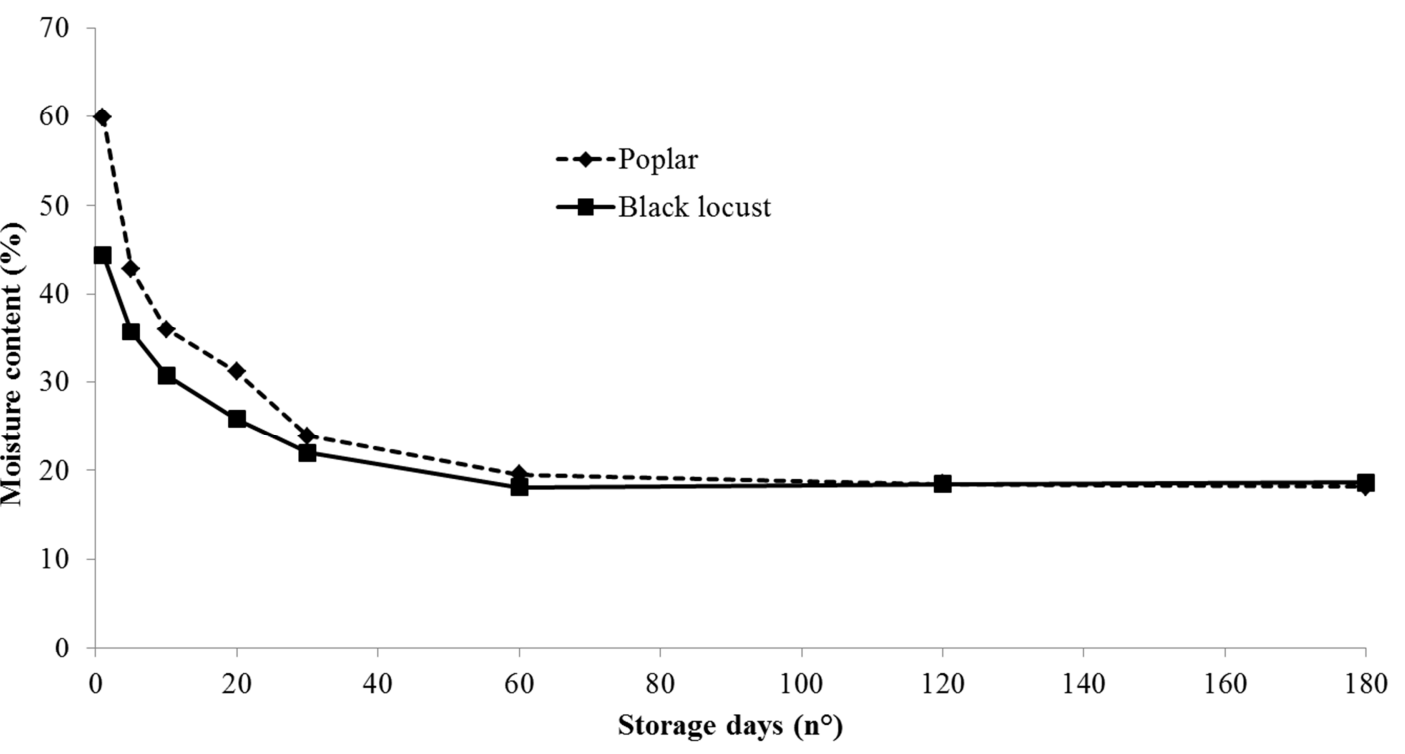

1

Fig. 4: Moisture content (average of all $\operatorname{logs} 150 \mathrm{~mm}$ in diameter) of piles during the six-month 3 storage period for both forestry tree species tested.

4

5 


\section{Tables}

2

3 Table 1: Experimental design for determining the influence of logs' diameter on wood drying

\begin{tabular}{ccc}
\hline \multirow{2}{*}{$\begin{array}{c}\text { Diameter } \\
(\mathrm{mm})\end{array}$} & \multicolumn{2}{c}{$\operatorname{logs}\left(\mathrm{n}^{\circ}\right)$} \\
\cline { 2 - 3 } & Poplar & Black locust \\
\hline 50 & 3 & 3 \\
100 & 3 & 3 \\
150 & 3 & 3 \\
200 & 3 & 3 \\
250 & 3 & 3 \\
\hline
\end{tabular}

4

5 
1 Table 2: Experimental design for determining the influence of logs' position in the pile on wood 2 drying

\begin{tabular}{ccc}
\hline \multirow{2}{*}{$\begin{array}{c}\text { Sampling } \\
\text { height }(\mathrm{m})\end{array}$} & \multicolumn{2}{c}{$\operatorname{logs}\left(\mathrm{n}^{\circ}\right)$} \\
\cline { 2 - 3 } & Poplar & Black locust \\
\hline 0.0 & 3 & 3 \\
0.5 & 3 & 3 \\
1.0 & 3 & 3 \\
1.5 & 3 & 3 \\
2.0 & 3 & 3 \\
2.5 & 3 & 3 \\
3.0 & 3 & 3 \\
\hline
\end{tabular}

3

4 
1 Table 3: Moisture content of logwood with different diameters during whole storage period

\begin{tabular}{|c|c|c|c|c|c|c|c|c|c|c|}
\hline \multirow{2}{*}{ Species } & \multirow{2}{*}{$\begin{array}{c}\text { Diameter } \\
(\mathrm{mm})\end{array}$} & & \multicolumn{8}{|c|}{ Storage days $\left(\mathrm{n}^{\circ}\right)$} \\
\hline & & & 1 & 5 & 10 & 20 & 30 & 60 & 120 & 180 \\
\hline \multirow{15}{*}{ Poplar } & \multirow[t]{3}{*}{50} & Mean & $60 \mathrm{a}$ & $42 a$ & $35 a$ & $30 \mathrm{a}$ & $23 a$ & $20 \mathrm{a}$ & $19 a$ & $19 a$ \\
\hline & & $S D$ & 0.58 & 1.52 & 0.58 & 2.00 & 1.00 & 1.52 & 1.52 & 0.58 \\
\hline & & $\operatorname{MCR}(\%)$ & - & 31 & 43 & 50 & 61 & 66 & 68 & 69 \\
\hline & \multirow[t]{3}{*}{100} & Mean & $60 \mathrm{a}$ & $40 \mathrm{ab}$ & $37 \mathrm{~b}$ & $32 b$ & $25 b$ & $19 \mathrm{a}$ & $18 \mathrm{a}$ & $18 \mathrm{a}$ \\
\hline & & $S D$ & 0.58 & 1.15 & 1.00 & 0.58 & 0.58 & 1.00 & 0.58 & 1.00 \\
\hline & & $\operatorname{MCR}(\%)$ & - & 33 & 40 & 47 & 59 & 69 & 70 & 70 \\
\hline & \multirow[t]{3}{*}{150} & Mean & $61 \mathrm{a}$ & $44 \mathrm{~b}$ & $39 c$ & $31 b$ & $28 \mathrm{bc}$ & $20 \mathrm{a}$ & $19 a$ & $18 \mathrm{a}$ \\
\hline & & $S D$ & 1.15 & 1.00 & 1.00 & 1.74 & 1.52 & 0.58 & 1.00 & 0.58 \\
\hline & & $\operatorname{MCR}(\%)$ & - & 27 & 36 & 49 & 54 & 66 & 69 & 71 \\
\hline & \multirow[t]{3}{*}{200} & Mean & $61 \mathrm{a}$ & $47 c$ & $41 c$ & $35 c$ & $31 \mathrm{~cd}$ & $21 \mathrm{a}$ & $19 a$ & $18 \mathrm{a}$ \\
\hline & & $S D$ & 1.15 & 1.00 & 1.52 & 0.58 & 1.00 & 1.00 & 1.00 & 0.58 \\
\hline & & $\operatorname{MCR}(\%)$ & - & 23 & 32 & 43 & 49 & 65 & 69 & 70 \\
\hline & \multirow[t]{3}{*}{250} & Mean & $61 a$ & $48 c$ & $44 d$ & $36 c$ & $33 d$ & $22 \mathrm{a}$ & $20 \mathrm{a}$ & $19 a$ \\
\hline & & $S D$ & 0.58 & 0.58 & 0.58 & 0.58 & 1.00 & 1.00 & 1.52 & 0.58 \\
\hline & & $\operatorname{MCR}(\%)$ & - & 20 & 27 & 40 & 46 & 65 & 68 & 69 \\
\hline \multirow{15}{*}{$\begin{array}{l}\text { Black } \\
\text { locust }\end{array}$} & \multirow[t]{3}{*}{50} & Mean & $46 a$ & $34 a$ & $30 \mathrm{a}$ & $25 a$ & $21 \mathrm{a}$ & $19 a$ & $18 \mathrm{a}$ & $18 \mathrm{a}$ \\
\hline & & $S D$ & 0.58 & 0.58 & 1.15 & 0.58 & 1.00 & 0.58 & 1.00 & 1.00 \\
\hline & & $\operatorname{MCR}(\%)$ & - & 25 & 34 & 45 & 54 & 59 & 61 & 61 \\
\hline & \multirow[t]{3}{*}{100} & Mean & $45 a$ & $34 \mathrm{a}$ & $31 \mathrm{ab}$ & $27 b$ & $23 b$ & $18 \mathrm{a}$ & $18 \mathrm{a}$ & $18 \mathrm{a}$ \\
\hline & & $S D$ & 1.00 & 1.52 & 1.00 & 0.58 & 1.15 & 1.00 & 0.58 & 1.52 \\
\hline & & $\operatorname{MCR}(\%)$ & - & 24 & 31 & 41 & 50 & 60 & 59 & 59 \\
\hline & \multirow[t]{3}{*}{150} & Mean & $45 \mathrm{a}$ & $38 b$ & $34 \mathrm{c}$ & $30 \mathrm{c}$ & $27 \mathrm{c}$ & $20 \mathrm{a}$ & $19 a$ & $18 \mathrm{a}$ \\
\hline & & $S D$ & 1.00 & 1.00 & 0.58 & 1.00 & 0.58 & 0.58 & 0.58 & 0.58 \\
\hline & & $\operatorname{MCR}(\%)$ & - & 16 & 25 & 33 & 39 & 56 & 59 & 59 \\
\hline & \multirow[t]{3}{*}{200} & Mean & $46 a$ & $42 c$ & $36 d$ & $33 d$ & $29 \mathrm{~cd}$ & $20 \mathrm{a}$ & $19 a$ & $19 a$ \\
\hline & & $S D$ & 0.58 & 0.58 & 2.08 & 1.00 & 1.52 & 0.58 & 0.58 & 1.00 \\
\hline & & $\operatorname{MCR}(\%)$ & - & 9 & 20 & 28 & 36 & 53 & 59 & 59 \\
\hline & \multirow[t]{3}{*}{250} & Mean & $46 a$ & $43 c$ & $38 \mathrm{e}$ & $34 d$ & $30 \mathrm{~d}$ & $21 \mathrm{a}$ & $19 a$ & $19 a$ \\
\hline & & $S D$ & 1.00 & 1.00 & 1.00 & 1.15 & 0.58 & 1.00 & 0.58 & 0.58 \\
\hline & & $\operatorname{MCR}(\%)$ & - & 7 & 17 & 27 & 34 & 54 & 59 & 57 \\
\hline
\end{tabular}

2 Notes: SD = Standard Deviation; MCR = Moisture Content Reduction

3 Different letters indicate significant differences between treatments for $\alpha=0.05$. 
1 Table 4: Internal moisture of logs of $100 \mathrm{~mm}$ in diameter of different tree species placed at

2 different heights in the pile during whole storage period

\begin{tabular}{|c|c|c|c|c|c|c|c|c|c|c|}
\hline \multirow{2}{*}{ Species } & \multirow{2}{*}{$\begin{array}{l}\text { Height } \\
\text { (m) }\end{array}$} & & \multicolumn{8}{|c|}{ Storage days $\left(\mathrm{n}^{\circ}\right)$} \\
\hline & & & 1 & 5 & 10 & 20 & 30 & 60 & 120 & 180 \\
\hline \multirow{21}{*}{ Poplar } & 0.0 & Mean & $61 \mathrm{a}$ & $50 \mathrm{a}$ & $40 a$ & $33 a$ & $26 a$ & $20 a$ & $20 a$ & $19 a$ \\
\hline & & $S D$ & 1.52 & 1.52 & 1.15 & 1.00 & 1.52 & 0.58 & 1.00 & 0.58 \\
\hline & & $\operatorname{MDR}(\%)$ & - & 17 & 35 & 46 & 57 & 66 & 66 & 69 \\
\hline & 0.5 & Mean & $60 \mathrm{a}$ & $48 b$ & $37 b$ & $31 b$ & $25 \mathrm{ab}$ & $19 \mathrm{a}$ & $18 \mathrm{a}$ & $18 \mathrm{a}$ \\
\hline & & $S D$ & 0.58 & 0.58 & 1.00 & 0.58 & 0.58 & 2.00 & 0.58 & 0.58 \\
\hline & & MDR (\%) & - & 20 & 38 & 47 & 59 & 68 & 69 & 69 \\
\hline & 1.0 & Mean & $60 \mathrm{a}$ & $42 c$ & $35 c$ & $30 b$ & $23 b$ & $19 a$ & $18 \mathrm{a}$ & $18 \mathrm{a}$ \\
\hline & & $S D$ & 0.58 & 1.15 & 1.00 & 0.58 & 0.58 & 1.00 & 0.58 & 1.00 \\
\hline & & $\operatorname{MDR}(\%)$ & - & 31 & 42 & 50 & 61 & 69 & 70 & 70 \\
\hline & 1.5 & Mean & $59 a$ & $41 c$ & $36 b c$ & $31 b$ & $23 b$ & $19 a$ & $18 \mathrm{a}$ & $18 \mathrm{a}$ \\
\hline & & $S D$ & 1.15 & 0.58 & 0.58 & 0.58 & 1.00 & 1.52 & 0.58 & 0.58 \\
\hline & & MDR (\%) & - & 30 & 39 & 47 & 61 & 67 & 70 & 71 \\
\hline & 2.0 & Mean & $60 \mathrm{a}$ & $41 c$ & $35 c$ & $30 \mathrm{~b}$ & $24 b$ & $19 a$ & $17 \mathrm{a}$ & $18 \mathrm{a}$ \\
\hline & & $S D$ & 0.58 & 1.00 & 1.00 & 0.58 & 0.58 & 1.52 & 0.58 & 0.58 \\
\hline & & MDR (\%) & - & 31 & 41 & 49 & 60 & 68 & 71 & 70 \\
\hline & 2.5 & Mean & $60 \mathrm{a}$ & $41 c$ & $34 c$ & $31 b$ & $24 b$ & $20 a$ & $18 \mathrm{a}$ & $19 a$ \\
\hline & & $S D$ & 0.58 & 1.00 & 0.58 & 1.00 & 0.58 & 1.00 & 0.58 & 0.58 \\
\hline & & $\operatorname{MDR}(\%)$ & - & 32 & 43 & 49 & 61 & 67 & 70 & 69 \\
\hline & 3.0 & Mean & $59 a$ & $42 c$ & $34 c$ & $31 b$ & $23 b$ & $20 a$ & $19 a$ & $18 \mathrm{a}$ \\
\hline & & $S D$ & 0.58 & 1.00 & 0.58 & 0.58 & 1.15 & 1.15 & 0.58 & 1.00 \\
\hline & & MDR (\%) & - & 29 & 42 & 47 & 62 & 67 & 69 & 70 \\
\hline \multirow{21}{*}{$\begin{array}{l}\text { Black } \\
\text { locust }\end{array}$} & 0.0 & Mean & $44 a$ & $39 a$ & $32 \mathrm{ab}$ & $26 a b$ & $23 a$ & $20 a$ & $20 a$ & $19 a$ \\
\hline & & $S D$ & 1.15 & 0.58 & 0.58 & 1.00 & 1.15 & 0.58 & 1.15 & 1.00 \\
\hline & & $\operatorname{MDR}(\%)$ & - & 11 & 28 & 40 & 48 & 55 & 54 & 58 \\
\hline & 0.5 & Mean & $45 a$ & $37 b$ & $31 b$ & $26 a b$ & $22 \mathrm{a}$ & $18 \mathrm{a}$ & $18 \mathrm{a}$ & $19 a$ \\
\hline & & $S D$ & 1.00 & 1.52 & 0.58 & 1.00 & 1.00 & 1.00 & 0.58 & 1.00 \\
\hline & & $\operatorname{MDR}(\%)$ & - & 17 & 32 & 42 & 51 & 60 & 59 & 58 \\
\hline & 1.0 & Mean & $45 a$ & $34 c$ & $31 b$ & $27 \mathrm{a}$ & $23 a$ & $18 \mathrm{a}$ & $18 \mathrm{a}$ & $18 \mathrm{a}$ \\
\hline & & $S D$ & 1.00 & 1.52 & 1.00 & 0.58 & 1.15 & 1.00 & 0.58 & 1.52 \\
\hline & & $\operatorname{MDR}(\%)$ & - & 24 & 31 & 41 & 50 & 60 & 59 & 59 \\
\hline & 1.5 & Mean & $44 a$ & $39 a$ & $31 b$ & $26 a b$ & $23 a$ & $18 \mathrm{a}$ & $18 \mathrm{a}$ & $18 \mathrm{a}$ \\
\hline & & $S D$ & 1.52 & 1.00 & 1.00 & 1.52 & 1.15 & 1.52 & 1.00 & 1.00 \\
\hline & & $\operatorname{MDR}(\%)$ & - & 21 & 29 & 40 & 48 & 60 & 59 & 59 \\
\hline & 2.0 & Mean & $45 a$ & $35 b c$ & $30 \mathrm{~b}$ & $25 b$ & $21 \mathrm{ab}$ & $18 \mathrm{a}$ & $17 \mathrm{a}$ & $19 a$ \\
\hline & & $S D$ & 0.58 & 1.15 & 1.00 & 1.15 & 0.58 & 1.52 & 0.58 & 1.15 \\
\hline & & $\operatorname{MDR}(\%)$ & - & 22 & 33 & 45 & 54 & 60 & 61 & 58 \\
\hline & 2.5 & Mean & $44 a$ & $33 c$ & $31 b$ & $26 a b$ & $22 a$ & $18 \mathrm{a}$ & $18 \mathrm{a}$ & $19 a$ \\
\hline & & $S D$ & 1.52 & 1.15 & 0.58 & 1.15 & 1.15 & 1.15 & 0.58 & 0.58 \\
\hline & & $\operatorname{MDR}(\%)$ & - & 24 & 30 & 40 & 49 & 60 & 58 & 56 \\
\hline & 3.0 & Mean & $45 a$ & $35 c$ & $30 \mathrm{~b}$ & $25 b$ & $20 \mathrm{ab}$ & $18 \mathrm{a}$ & $19 a$ & $19 a$ \\
\hline & & $S D$ & 1.15 & 0.58 & 1.52 & 0.58 & 0.58 & 0.58 & 1.15 & 1.52 \\
\hline & & $\operatorname{MDR}(\%)$ & - & 22 & 32 & 45 & 54 & 59 & 58 & 58 \\
\hline
\end{tabular}

3 Notes: $\mathrm{SD}=$ Standard Deviation; $\mathrm{MCR}=$ Moisture Content Reduction

Different letters indicate significant differences between treatments for $\alpha=0.05$. 
1 Table 5: ANOVA table for diameter and position of logs at end of storage period (180 days)

\begin{tabular}{llccccc}
\hline & DF & SS & $\%$ & F-Value & P-Value \\
\hline \multirow{2}{*}{ Log position } & Species & 1 & 2.380 & 6 & 2.43 & 0.129 \\
& Position & 6 & 7.286 & 19 & 1.24 & 0.314 \\
& Interaction & 6 & 1.285 & 4 & 0.21 & 0.967 \\
& Residual & 28 & 27.333 & 71 & & \\
\hline \multirow{2}{*}{ Log diameter } & Species & 1 & 0.592 & 2 & 0.65 & 0.423 \\
& Size & 6 & 5.282 & 15 & 0.97 & 0.456 \\
& Interaction & 4 & 1.764 & 5 & 0.49 & 0.742 \\
& Residual & 30 & 27.000 & 78 & & \\
\hline
\end{tabular}

2

Statistically significant interval $=0.05$

3 
1 Table 6: ANOVA table for diameter and position of logs 60 days after pile building

\begin{tabular}{llccccc}
\hline & DF & SS & $\%$ & F-Value & P-Value \\
\hline \multirow{2}{*}{ Log position } & Species & 1 & 20.024 & 24 & 11.68 & 0.014 \\
& Position & 6 & 11.000 & 14 & 1.06 & 0.404 \\
& Interaction & 6 & 2.809 & 3 & 0.27 & 0.944 \\
& Residual & 28 & 48.000 & 59 & & \\
\hline \multirow{2}{*}{ Log diameter } & Species & 1 & 1.333 & 2 & 0,82 & 0,026 \\
& Size & 6 & 15.750 & 21 & 1,63 & 0,173 \\
& Interaction & 4 & 8.117 & 11 & 1,25 & 0.307 \\
& Residual & 30 & 48.333 & 66 & & \\
\hline
\end{tabular}

2 Statistically significant interval $\alpha=0.05$

3 
1 Table 7: Air temperature and internal temperature of logs of different

2 different heights in the pile during whole storage period

\begin{tabular}{|c|c|c|c|c|c|c|c|c|c|c|}
\hline \multirow{2}{*}{\multicolumn{3}{|c|}{ Height (m) }} & \multicolumn{7}{|c|}{ Storage (days) } & \multirow{3}{*}{$\frac{180}{19.3}$} \\
\hline & & & 1 & 5 & 10 & 20 & 30 & 60 & 120 & \\
\hline Air & & mean & 3.0 & 8.9 & 8.9 & 12.8 & 13.8 & 15.5 & 19.7 & \\
\hline \multirow{14}{*}{ Poplar } & 0.0 & mean & 2.5 & 8.8 & 8.3 & 12.3 & 13.3 & 15.6 & 20.0 & 19.5 \\
\hline & & $S D$ & 0.44 & 0.26 & 0.46 & 0.31 & 0.46 & 0.17 & 0.20 & 0.20 \\
\hline & 0.5 & mean & 2.7 & 8.7 & 8.4 & 12.5 & 13.5 & 15.5 & 19.7 & 19.6 \\
\hline & & $S D$ & 0.36 & 0.40 & 0.26 & 0.32 & 0.42 & 0.46 & 0.31 & 0.10 \\
\hline & 1.0 & mean & 2.9 & 8.8 & 8.5 & 12.9 & 13.2 & 15.7 & 19.7 & 19.2 \\
\hline & & $S D$ & 0.25 & 0.38 & 0.32 & 0.30 & 0.35 & 0.40 & 0.26 & 0.15 \\
\hline & 1.5 & mean & 3.0 & 9.1 & 8.6 & 9.6 & 13.4 & 15.6 & 19.9 & 19.5 \\
\hline & & $S D$ & 0.1 & 0.42 & 0.15 & 5.52 & 0.47 & 0.06 & 0.12 & 0.26 \\
\hline & 2.0 & mean & 2.8 & 8.4 & 8.6 & 12.5 & 13.5 & 15.5 & 19.7 & 19.2 \\
\hline & & $S D$ & 0.21 & 0.25 & 0.06 & 0.46 & 0.31 & 0.15 & 0.10 & 0.10 \\
\hline & 2.5 & mean & 2.8 & 8.9 & 8.2 & 12.6 & 13.4 & 15.7 & 19.8 & 19.1 \\
\hline & & $S D$ & 0.20 & 0.25 & 0.10 & 0.30 & 0.51 & 0.26 & 0.10 & 0.25 \\
\hline & 3.0 & mean & 2.9 & 8.8 & 8.1 & 12.5 & 13.6 & 15.4 & 19.5 & 19.3 \\
\hline & & $S D$ & 0.25 & 0.26 & 0.20 & 0.10 & 0.20 & 0.20 & 0.06 & 0.47 \\
\hline \multirow{14}{*}{ Black locust } & 0.0 & mean & 2.4 & 8.5 & 8.1 & 12.4 & 13.4 & 15.5 & 19.9 & 19.5 \\
\hline & & $S D$ & 0.15 & 0.10 & 0.40 & 0.59 & 0.52 & 0.35 & 0.25 & 0.15 \\
\hline & 0.5 & mean & 2.5 & 8.8 & 8.5 & 12.4 & 13.6 & 15.3 & 19.6 & 19.5 \\
\hline & & $S D$ & 0.51 & 0.25 & 0.06 & 0.42 & 0.55 & 0.31 & 0.32 & 0.32 \\
\hline & 1.0 & mean & 2.9 & 8.6 & 8.3 & 12.7 & 13.3 & 15.4 & 19.6 & 19.3 \\
\hline & & $S D$ & 0.31 & 0.55 & 0.15 & 0.21 & 0.46 & 0.40 & 0.26 & 0.15 \\
\hline & 1.5 & mean & 2.7 & 8.7 & 8.4 & 9.4 & 13.4 & 15.4 & 19.7 & 19.5 \\
\hline & & $S D$ & 0.53 & 0.42 & 0.30 & 5.37 & 0.40 & 0.35 & 0.42 & 0.21 \\
\hline & 2.0 & mean & 2.8 & 8.8 & 8.4 & 12.4 & 13.8 & 15.3 & 19.5 & 19.3 \\
\hline & & $S D$ & 0.21 & 0.36 & 0.29 & 0.32 & 0.15 & 0.25 & 0.36 & 0.12 \\
\hline & 2.5 & mean & 2.5 & 8.7 & 8.3 & 12.5 & 13.5 & 15.4 & 19.6 & 19.1 \\
\hline & & $S D$ & 0.36 & 0.47 & 0.25 & 0.28 & 0.58 & 0.40 & 0.38 & 0.29 \\
\hline & 3.0 & mean & 2.8 & 8.5 & 8.1 & 12.4 & 13.8 & 15.2 & 19.3 & 19.2 \\
\hline & & $S D$ & 0.32 & 0.45 & 0.21 & 0.25 & 0.15 & 0.35 & 0.26 & 0.35 \\
\hline
\end{tabular}

3 Note: SD = Standard Deviation; statistical analysis could not detect any significant difference between readings taken inside the logs placed at

4 different heights in the pile and by the weather station (air); values in the table represent the average of the three individual readings obtained in three different logs for each treatment. 
1 Table 8: Air temperature and internal temperature of logs with different diameters and of different

2 forestry tree species during whole storage period

\begin{tabular}{|c|c|c|c|c|c|c|c|c|c|c|}
\hline \multirow{2}{*}{\multicolumn{3}{|c|}{ diameter $(\mathrm{mm})$}} & \multicolumn{8}{|c|}{ Storage (days) } \\
\hline & & & 1 & 5 & 10 & 20 & 30 & 60 & 120 & 180 \\
\hline Air & & mean & 3.0 & 8.9 & 8.9 & 12.8 & 13.8 & 15.5 & 19.7 & 19.3 \\
\hline \multirow{10}{*}{ Poplar } & 50 & mean & 2.7 & 8.7 & 8.5 & 12.6 & 13.6 & 15.4 & 19.8 & 19.3 \\
\hline & & $S D$ & 0.51 & 0.36 & 0.52 & 0.40 & 0.15 & 0.46 & 0.35 & 0.12 \\
\hline & 100 & mean & 2.9 & 8.6 & 8.3 & 12.8 & 31.3 & 15.6 & 19.5 & 19.4 \\
\hline & & $S D$ & 0.32 & 0.25 & 0.23 & 0.40 & 0.46 & 0.52 & 0.31 & 0.32 \\
\hline & 150 & mean & 2.8 & 8.7 & 8.8 & 12.8 & 13.4 & 15.4 & 19.6 & 19.1 \\
\hline & & $S D$ & 0.17 & 0.44 & 0.42 & 0.38 & 0.47 & 0.40 & 0.49 & 0.25 \\
\hline & 200 & mean & 2.9 & 8.8 & 8.7 & 12.8 & 13.5 & 15.7 & 19.6 & 19.3 \\
\hline & & $S D$ & 0.38 & 0.57 & 0.15 & 0.52 & 0.36 & 0.06 & 0.53 & 0.40 \\
\hline & 250 & mean & 2.6 & 8.9 & 8.7 & 12.7 & 13.4 & 15.7 & 19.5 & 19.4 \\
\hline & & $S D$ & 0.35 & 0.25 & 0.21 & 0.59 & 0.53 & 0.21 & 0.32 & 0.21 \\
\hline \multirow{10}{*}{ Black locust } & 50 & mean & 2.9 & 8.6 & 8.2 & 12.5 & 13.7 & 15.4 & 19.8 & 19.3 \\
\hline & & $S D$ & 0.30 & 0.15 & 0.46 & 0.45 & 0.35 & 0.38 & 0.36 & 0.15 \\
\hline & 100 & mean & 2.7 & 8.7 & 8.4 & 12.6 & 13.4 & 15.1 & 19.5 & 19.3 \\
\hline & & $S D$ & 0.53 & 0.12 & 0.12 & 0.44 & 0.59 & 0.12 & 0.06 & 0.25 \\
\hline & 150 & mean & 2.8 & 08.8 & 8.2 & 12.6 & 13.5 & 15.2 & 19.8 & 19.3 \\
\hline & & $S D$ & 0.23 & 0.57 & 0.12 & 0.06 & 0.55 & 0.16 & 0.23 & 0.15 \\
\hline & 200 & mean & 2.8 & 8.7 & 8.5 & 9.5 & 13.7 & 15.5 & 19.5 & 19.4 \\
\hline & & $S D$ & 0.58 & 0.25 & 0.32 & 0.54 & 0.12 & 0.46 & 0.44 & 0.31 \\
\hline & 250 & mean & 2.6 & 9.1 & 8.3 & 12.5 & 13.6 & 15.5 & 19.3 & 19.4 \\
\hline & & $S D$ & 0.06 & 0.15 & 0.25 & 0.45 & 0.35 & 0.45 & 0.32 & 0.23 \\
\hline
\end{tabular}

3 Note: SD = Standard Deviation; statistical analysis could not detect any significant difference between readings taken inside the logs with different diameters and by the weather station (air); values in the table represent the average of the three individual readings obtained in three different logs for each treatment. 
Table 9: Initial and final values of HHV and LHV of logs of different sizes and tree species

\begin{tabular}{|c|c|c|c|c|c|}
\hline & \multirow{2}{*}{$\begin{array}{l}\text { Diameter } \\
(\mathrm{mm})\end{array}$} & \multicolumn{2}{|c|}{ Initial values $\left(\mathrm{MJ} \mathrm{kg}^{-1}\right)$} & \multicolumn{2}{|c|}{ Final values $\left(\mathrm{MJ} \mathrm{kg}^{-1}\right)$} \\
\hline & & HHV & LHV & HHV & LHV \\
\hline \multirow{5}{*}{ Poplar } & 50 & $18.69 \mathrm{a}$ & $7.05 a$ & $18.65 \mathrm{a}$ & $14.49 \mathrm{a}$ \\
\hline & 100 & $18.72 \mathrm{a}$ & $7.06 \mathrm{a}$ & $18.74 \mathrm{a}$ & $14.21 \mathrm{a}$ \\
\hline & 150 & $18.83 \mathrm{a}$ & $7.02 \mathrm{a}$ & $18.76 \mathrm{a}$ & $14.32 \mathrm{a}$ \\
\hline & 200 & $18.65 \mathrm{a}$ & $7.07 \mathrm{a}$ & $18.61 \mathrm{a}$ & $14.31 \mathrm{a}$ \\
\hline & 250 & $18.68 \mathrm{a}$ & $7.09 \mathrm{a}$ & $18.51 \mathrm{a}$ & $14.28 \mathrm{a}$ \\
\hline \multirow{5}{*}{ Black locust } & 50 & $18.05 b$ & $7.83 b$ & $18.06 \mathrm{~b}$ & $14.48 \mathrm{a}$ \\
\hline & 100 & $17.98 \mathrm{~b}$ & $7.84 \mathrm{~b}$ & $18.01 \mathrm{~b}$ & $14.26 \mathrm{a}$ \\
\hline & 150 & $18.12 b$ & $7.89 \mathrm{~b}$ & $17.97 \mathrm{~b}$ & $14.72 \mathrm{a}$ \\
\hline & 200 & $18.09 \mathrm{~b}$ & $7.93 b$ & $18.04 \mathrm{~b}$ & $14.36 \mathrm{a}$ \\
\hline & 250 & $18.01 \mathrm{~b}$ & $7.85 \mathrm{~b}$ & $18.06 \mathrm{~b}$ & $14.44 \mathrm{a}$ \\
\hline
\end{tabular}

2 Notes: HHV = Higher Heating Value; LHV = Lower Heating Value

3 Values in the table represent the average of the three individual readings obtained in three different logs for each treatment; different letters indicate significant differences between treatments for $\alpha=0.05$.

No statistical differences were obtained between initial HHV value and final HHV value referring to the same forestry tree species. 
2 Table 10: Initial and final values of HHV and LHV of logs of different forestry tree species placed

3 in different layers in the pile

\begin{tabular}{|c|c|c|c|c|c|}
\hline & \multirow{2}{*}{$\begin{array}{l}\text { Height from ground } \\
\text { (m) }\end{array}$} & \multicolumn{2}{|c|}{ Initial values $\left(\mathrm{MJ} \mathrm{kg}^{-1}\right)$} & \multicolumn{2}{|c|}{ Final values $\left(\mathrm{MJ} \mathrm{kg}^{-1}\right)$} \\
\hline & & HHV & LHV & HHV & LHV \\
\hline \multirow{7}{*}{ Poplar } & 0.0 & $18.72 \mathrm{a}$ & $7.06 a$ & $18.72 \mathrm{a}$ & $14.42 \mathrm{a}$ \\
\hline & 0.5 & $18.69 \mathrm{a}$ & $6.99 a$ & $18.62 \mathrm{a}$ & $14.39 \mathrm{a}$ \\
\hline & 1.0 & $18.82 \mathrm{a}$ & $6.98 \mathrm{a}$ & $18.82 \mathrm{a}$ & $14.23 \mathrm{a}$ \\
\hline & 1.5 & $18.74 \mathrm{a}$ & $7.01 \mathrm{a}$ & $18.71 \mathrm{a}$ & $14.24 \mathrm{a}$ \\
\hline & 2.0 & $18.78 \mathrm{a}$ & $7.08 \mathrm{a}$ & $18.76 \mathrm{a}$ & $14.34 \mathrm{a}$ \\
\hline & 2.5 & $18.83 \mathrm{a}$ & $7.05 \mathrm{a}$ & $18.79 \mathrm{a}$ & $14.47 \mathrm{a}$ \\
\hline & 3.0 & $18.78 \mathrm{a}$ & $7.07 \mathrm{a}$ & $18.73 \mathrm{a}$ & $14.33 \mathrm{a}$ \\
\hline \multirow{7}{*}{ Black locust } & 0.0 & $18.03 \mathrm{~b}$ & $7.75 b$ & $18.08 \mathrm{~b}$ & $14.54 \mathrm{a}$ \\
\hline & 0.5 & $18.05 b$ & $7.54 b$ & $18.06 \mathrm{~b}$ & $14.36 \mathrm{a}$ \\
\hline & 1.0 & $18.10 \mathrm{~b}$ & $7.62 b$ & $18.02 b$ & $14.41 \mathrm{a}$ \\
\hline & 1.5 & $17.97 \mathrm{~b}$ & $7.91 b$ & $18.01 \mathrm{~b}$ & $14.39 \mathrm{a}$ \\
\hline & 2.0 & $18.08 \mathrm{~b}$ & $7.41 \mathrm{~b}$ & $18.06 \mathrm{~b}$ & $14.45 \mathrm{a}$ \\
\hline & 2.5 & $17.98 \mathrm{~b}$ & $7.65 b$ & $18.04 \mathrm{~b}$ & $14.56 \mathrm{a}$ \\
\hline & 3.0 & $18.05 \mathrm{~b}$ & $7.39 \mathrm{~b}$ & $18.09 \mathrm{~b}$ & $14.57 \mathrm{a}$ \\
\hline
\end{tabular}

Notes: HHV = Higher Heating Value; LHV = Lower Heating Value

Values in the table represent the average of the three individual readings obtained in three different logs for each treatment; different letters indicate significant differences between treatments for $\alpha=0.05$.

No statistical differences were obtained between initial HHV value and final value HHV referring to the same forestry tree species. 
1 Table 11: Dry matter at the beginning and at the end of the storage period

\begin{tabular}{lcccc}
\hline & \multirow{2}{*}{$\begin{array}{c}\text { Diameter } \\
(\mathrm{mm})\end{array}$} & \multicolumn{2}{c}{ Dry matter $(\mathrm{kg})$} & p-Value \\
\cline { 3 - 4 } & 50 & 1.69 & 1.64 & 0.932 \\
\multirow{4}{*}{ Poplar } & 100 & 6.79 & 6.83 & 0.901 \\
& 150 & 14.11 & 14.23 & 0.898 \\
& 200 & 27.31 & 27.25 & 0.941 \\
& 250 & 41.23 & 41.05 & 0.902 \\
\hline \multirow{4}{*}{ Black locust } & 50 & 2.42 & 2.26 & 0.889 \\
& 100 & 11.08 & 11.21 & 0.884 \\
& 150 & 22.98 & 22.57 & 0.912 \\
& 200 & 42.12 & 41.95 & 0.956 \\
& 250 & 61.51 & 61.41 & 0.945 \\
\hline
\end{tabular}

2 